\title{
A REVIEW OF THE NATURE AND FUNCTION OF THE NEUROGLIA.
}

\author{
By CHARLES RICKSHER, M.D., \\ Pathologist, State Psychopathic Institute, Kankakee, Ill.
}

All advance in the study of the histology of the brain depends upon staining methods which will bring out the various elements and reveal the various parts of each element. In the study of the ganglion cells carmine was first used, then the silver impregnation of Golgi, and the methylene blue stain of Ehrlich, each of which advanced our knowledge but still left unanswered many questions regarding the exact structure and the changes which the cells undergo in pathological conditions. When Nissl brought out his method of staining with methylene blue, it was thought that the final step had been reached and that all the perplexing questions of histology and pathology would be solved. But in a short time this methed also showed its limitations and a search for new methods was instituted.

Until quite recently, the efforts of histologists and pathologists have been directed to the study of the ganglion cell and although it was recognized that under certain conditions there were changes in the neuroglia, it was thought that these were entirely secondary and that little would result from a study of these cells.

It was known for a long time that certain fibres seen in teased specimens belonged to cells other than ganglion cells but the real form of the neuroglia cells was hardly known until Golgi perfected his silver impregnation. In I895 Weigert brought out his method of staining the neuroglia fibres, and formulated certain functions of the neuroglia which for a time seemed satisfactory; but in a short time new investigations, notably those by Held, opened up new problems. The Weigert method while demonstrating the nucleus and fibres of the neuroglia cells gives no idea of the protoplasmic structure of the cell.

Many modifications of existing methods have been made and new methods developed in the last Io years, all with a view of giving a clearer idea of the structure of the whole cell and its 
relation to other cells and elements in the neighborhood. Alzheimer has done a great deal of work on the pathological neuroglia and Eisath has aided in showing us some of the problems involved in the study of the cell itself.

In preparations made according to Golgi's method one sees an irregular black center from which run an enormous number of expansions which may be traced for varying distances. Cajal divides the different types into three groups: (I) The fibrillar neuroglia cell with long expansions found especially in the white substance; (2) the neuroglia cell with short expansions, which Andriezen calls the protoplasmic cells, and which are found in the grey matter, and (3) the epithelial neuroglia cell.

The cell with the long expansions is the type first discovered because of the ease with which it is isolated. The body is small, 6-I I micra in diameter and irregular in shape. The filaments, to the number of 20 to 40 , run in every direction. Frequently several of these filaments run from the same pedicle, their course is irregular, they branch rarely and seem to terminate in a free extremity after a course of variable length.

The filaments have neither the same length nor the same destination. Cajal divides them into three categories: (I) The slender filaments, colored yellow or light brown by the silver chromate, terminating freely a short distance from their point of origin; (2) thick, long filaments which sometimes, in well impregnated sections, may be traced for more than a millimeter. Andriezen has shown how these fibres run to more or less distant bloodvessels and envelope them in a sort of neurogliar adventitia. According to him this sort of ending serves to protect the brain tissue from the shocks caused by the variations in the blood pressure; (3) vascular appendices, discovered by Golgi, which are ordinarily thick and undivided and run almost horizontally, and end by terminating in a thick cone adherent to the endothelium of a capillary.

Ranvier, who studied principally the long fibres of the white substance, thought they had neither beginning nor end, running from one cell to another. He said that the body of the cell was not the place of origin, but only a place where several fibres coming from different directions intercrossed and traversed its granular protoplasm. This opinion was supported by Weigert, who said that it was not possible to determine the ends of the fibres, and 
that also these fibres do not anastomose and that they pass from one neuroglia corpuscle to another without contracting with their protoplasm any connections other than those of contiguity. Other histologists denied this and said that the fibres were in connection with the cell protoplasm and that they had terminations which were free.

Cajal gives the following reasons supporting the latter view: The expansions of the embryonic neuroglia cells terminate freely; the vascular pedicle and the longest prolongations of the neuroglia corpuscle terminate always in an independent extremity; the expansions of the cells of the grey matter run only a short distance and always terminate in free ends. In the cerebellum the longer fibres often traverse the granular and molecular layers and their free extremity touches either the inferior surface of the pia mater, or the external surface of the endothelium of the capillaries.

The cells in the grey matter have a larger number of processes than those in white and are relatively much shorter. Each process is covered with irregular excrescences or short appendices or spines; they all terminate at the same distance from the cell body and do not stain by Weigert's neurogliar stain. According to their form, situation and their connections with the ganglion cells in the cortex, many subdivisions may be made.

Held, who has made important contributions to the study of the neuroglia, has shown that the neuroglia, besides the fibres, also produces other structures which take the character of a syncytial web. Held thinks that this reticulum includes Bethe's Füllnetze as well as the Golgi net which are considered by some as being identical. The protoplasmic processes of the neuroglia cells branch and these branches from various cells join to form a net-like structure which is found throughout the central nervous system. Held also describes as part of syncytial neurogliar structures the Membrana neuroglia superficialis et perivascularis, the former separating the cortex from the pia, and the latter the vessels from the nervous structures.

This neurogliar reticulum is best seen in the superficial layers of the cortex. Alzheimer states by no method of staining has he been able to demonstrate it in the deeper layers. The reticulum serves as a support and as Held thinks, also, as a filter for the lymph, 
which nourishes the ganglion cells. At present there is no doubt as to the existence of this neurogliar reticular network and it is probable that all, or the majority of the neurogliar cells in the central nervous system contribute in some part to it.

In Golgi preparations a large number of long processes are seen extending from each cell. These cross and form a thick network of fibres which is best seen in sections from the white matter. Many of the processes are seen to end on the adventitial wall of the blood-vessels and one may conclude that some processes from every cell end in this fashion.

In sections stained by Eisath's method, or by Alzheimer's modification, one may find, especially in the grey matter, another type of cell. This consists of a nucleus surrounded by a small rim of protoplasm from which, in all directions, run protoplasmic processes. These branch and become smaller and smaller until they can be followed no further. These cells apparently do not enter into the formation of a reticulum. In good preparations one may follow the processes for a long distance, but in none are the processes as numerous as in the Golgi preparations due, in part at least, to the fact that the sections are thinner. Many of the cells have processes attached to the blood-vessels as in the silver impregnation specimens.

By the same method one may find cells consisting of a nucleus with a little granular protoplasm on one side, and on the other a comparatively large open space the whole surrounded by a line of granules. No processes can be seen to extend from these cells. Alzheimer has shown that there is a certain resemblance between these cells and the ganglion cells found in Nissl preparations in which there has been a tear in the protoplasmic body, due to the shrinking of the cell membrane by the fixing fluid. The relation of these two last groups of cells to each other and to the neuroglia reticulum as well as their biological significance is as yet unknown.

In pathological conditions, types of cells other than those described above are seen. Alzheimer, in his work on general paralysis, described cells which showed large protoplasmic cell bodies which disintegrated without having produced any fibres. On account of their form and general morphological character, he called them " amoboid glia cells." Eisath also described the same cells as occurring in large numbers in acute cases of dementia 
præcox. Further investigations have shown that these cells occur in many other acute disorders of the nervous system.

All the observations have shown that the amœboid cells are short lived and in some sections one may find all stages of development. In different preparations, one may find the cells filled with granules which indicate some devolutional process.

In general paralysis, Nissl found long slender cells which stained rather darkly with methylene blue and showed only a small amount of protoplasm. To these cells he gave the name "Stäbchenzellen" and considered them as of gliotic origin. Cerletti, in a study of these cells, showed that many which appeared to be typical "Stäbchenzellen" in toluidin blue preparations proved to be adventitial or endothelial cells when stained by Mann's method or by resorcinfuchsin. There are, however, doubtless some "Stäbchenzellen" which are of gliotic origin and these must be carefully distinguished from those of mesodermal origin.

Our knowledge of the function of the neuroglia cells is slight. Their position in the brain substance without processes extending to the outside excludes them from much experimental work. Consequently the comparative biological and the pathological observations have so far been the only paths open to investigation and most of the work done has been performed in this indirect fashion. There have been many theories as to the function of the neuroglia of which the following are the most important: Golgi and his pupils thought that the neuroglia acted as an intermediary between the vessels and the neurones, and served to convey nutriment from the former to the latter. According to this view the capillaries, neuroglia cells and dentrites formed a unit having for its function the nourishment of the neurone. Against this view, according to Cajal, are the following objections: (I) the protoplasmic prolongations of the neurones never terminate on the vessels or on the neuroglia fibres, as Kolliker, Weigert, Lavdowski and others have shown, (2) when the neurones seem to be enveloped by special neuroglia cells these never send any fibres to the neighboring capillaries, (3) the neuroglia cells of the white matter are lacking in fishes, batrachians, and reptiles and the epithelial corpuscles which represent them have no connection with the vessels. 
Weigert thought the neuroglia played a purely passive rôle, that of filling the vacant spaces between the expansions of the neurones. In favor of this view, he argued that the neuroglia was abundant in the place where the nervous plexus occupied little space and rare where the nervous net was abundant. When there was destruction of the nerve cells by some pathological process, there was a proliferation of the neuroglia and partial obliteration of the cavity formed by the necrosis. Since the discovery of other stains which show the protoplasmic structure of the neuroglia cells and the various stages of development and decay of the cell, Weigert's views are not considered to give a definite idea of the function of the cells.

The view that the neuroglia acts as an insulator, that the fibrils are always disposed in such a way as to prevent contact between the non-myelinated nerve fibrils and between the dendrites is advanced by Cajal, Sala, and Terrazas. In favor of this theory Cajal brings the following facts:

(I) The neuroglia fibres of the grey substance in the superior vertebrates and the lateral expansions of the epithelial corpuscles in the inferior are remarkably abundant in the regions where the dendrites are most numerous. Here they prevent contact not only between dendrites of neighboring cells, but between these dendrites and the non-myelinated axis-cylinders.

(2) The neuroglia abounds in regions where the intercellular connections are numerous and complicated and it is abundant there not because contacts exist but because these contacts ought to be regulated and in some way they are led to some particular group of terminal nervous ramifications by the neuroglia.

Cajal brings forth other reasons based on comparative anatomy to support this theory and cites similar functional activity of the epithelial cells in the lower vertebrates.

Lugaro, in a paper based in part on the work of Cajal, gives the following as the functions of the neuroglia: ( $I$ ) the fibres of the neuroglia support and add elasticity to the nerve tissue, (2) the protoplasm of the neuroglia cells acts as an insulating medium confining nerve stimuli to their proper line of neurones and preventing leakage of energy, (3) the protoplasm of the neuroglia cell acts as a filter for toxic products of normal metabolism and renders them innocuous. The toxic products may be in part in the blood 
and in part in the nerve elements, and possibly the neuroglia cells prevent toxic agents in the blood from damaging the neurones. It is probable that nervous excitations at articulations of neighboring neurones may be of a chemical nature, and it is possible that here also the neuroglia cells may take some part in the process, perhaps by eliminating waste products, which may be formed, (4) in pathological'conditions, the neuroglia cells acquire perverted activity and may become the source of toxic substances. The importance of this in many affections of the nervous system is obvious, if somewhat theoretical, (5) the neuroglia may exercise nutritive or chemical influences in the process of development, although the part played is difficult to define.

Mawas has brought forth the view that the neuroglia has also a glandular function. While studying the cells composing the ciliary retina, he demonstrated that these cells considered by most as being of the order of neuroglia are endowed with a secretory activity. After studying the ependymal neuroglia, he concluded that (I) the ependymal neuroglia cells of vertebrates presented a marked variation in the chromaticity of the nucleus, which is an important morphological manifestation of glandular activity (2) the protoplasm of the ependymal cells, neuroglia cells and their prolongations show among other details mitochondrial formations, recesses, granules, and lipoid enclosures. The mitochondrials in the ependymal cells occupy the supranuclear zone, but one can see them throughout the cell. In the neuroglia cells the mitochondrial elements are placed in the protoplasm without definite order and surround the nucleus. The granules exist in the prolongations of the neuroglia fibres where they form the majority if not all, the bodies which are called the "Givre de Boll." The vesicles of lipoid deposits are characterized by a highly colored cortex and clear center. Thus, according to him, the neuroglia cells present the character of actual secretory organs and form an immense gland diffused throughout the nervous system.

That the neuroglia cells may take up a phagocytic action, is now generally accepted by the majority of neuropathologists. Marinesco has indicated that a distinct antagonism exists between nerve and neuroglia cells. Nissl states that the neuronophages are of neurogliar origin and terms them "Gitterzellen." He further admits that leucocytes may become neurophagocytic, but are apt 
themselves to finally degenerate and be devoured by the "Gitterzellen." Cajal, Lugaro and Marinesco emphasize the importance of the small neuroglia cells seen in the neighborhood of nerve cells in healthy, but especially in pathological, states in which latter they often proliferate and become very numerous. These cells, which normally appear to consist of a nucleus only, are exceedingly susceptible to all toxic agencies which affect nervous tissues, increasing in size and numbers in an extraordinary fashion, these they term satellite cells. Marinesco in his book, "La Cellule Nerveuse" proves these satellite cells to be of neurogliar origin.

Marinesco described several experiments which indicated the complex nature of neuronophagy and concluded that the main condition for its production was the death or the necrosis of the nerve cell, which, by a kind of positive chemiotaxis, attracts the phagocytes which are always motile cells and of mesodermic origin. The attack never takes place when the nerve cell is still living, so that the process might be called a neuronecrophagy. The spaces left after the absorption of the dead nerve cells are filled by cellular and fibrillary proliferation of the neurogliar tissue.

In a short review it is not possible to clearly state or abstract all the work done along this line, but it is hoped that enough has been said to give a general idea of the present day views of the nature and functions of the neuroglia.

The problems yet to be solved are many. The action of the neuroglia to endogenous and exogenous toxines, the relation of the fibres and cells to the neurones and to the nutritive processes of the brain, are far from being clearly stated. While many theories have been advanced, all are still in the stage of theory and are not at all proven. The pathological significance of the neuroglia is probably as important a subject as is that relating to the normal relation of the neuroglia to surrounding structures. Alzheimer's work has opened up vast fields for study-the determination of the origin of the amøboid cells, the processes concerned in their production and what factors stimulate their development, the nature and significance of the various granules which may be seen in them all of which are questions which will require a great deal of study and experimentation to settle.

But with the advance of histological methods and the realization of the fact that it is necessary to improve technic and methods will, 
without doubt, produce the solution of many of the problems of the neuroglia and probably also many of those of psychiatry in general.

WORKS CONSULTED.

A. Alzheimer: Histologische Studien zur differenzial Diagnose der progressiven Paralyse. Nissl's Arbeiten, Vol. I, H. I, 1904.

A. Alzheimer: Beiträge zur Kenntnis der pathologischen Neuroglia und ihrer Beziehungen zu den Abbauvorgangen in Nervengewebe. Nissl's Arbeiten, Vol. III, H. 3, 19 Io.

S. Raymon Cajal: Histologie due Systeme Nerveux de l'Homme et des Vertébrés. Vol. I, 1909, p. 230.

Ugo Cerletti: Zur Stäbchenzellenfrage. Folic Neurogiologia, B. III, No. 7, 1910, p. 658.

Geo. Eisath: Weitere Beobachtungen ueber das Menschlichen Nervenstützgewebe. Archiv f. Psychiatrie und Nervenkrankheiten. Vol. XLVIII, I9I I, p. 896.

E. Fankhauser: Zur Kenntnis der protoplasmatischen Glia. Journal für Psychologie und Neurologie. Vol. XVII, 1910, p. 19.

Hans Held: Ueber die Neuroglia marginalis der Menschlichen Grosshirnrinde. Monatsschrift für Psychiatrie und Neurologie. Vol. XXVI, 1909, p. 360.

E. Lugaro: Article, Allgemeine pathologische Anatomie der Neuroglia. Handbuch der pathologischen Anatomie des Nervensystems. Vol. I, 1904.

E. Lugaro: On the functions of the Neuroglia. Arch. Ital. de Biol., T. 48, f. 3, 1908, p. 357. Abstract in Rev. of Neurol. and Psychiatry. Vol. VI, 1908, p. 587 .

J. Mawas: Note sur la Structure et les Signification Glandulaire probable du Cellules Neurogliques du Systeme Nerveux Central das Vertébrés. Compt. rendu. Soc., de Biologie, T. 69, 1910, p. 45.

C. J. Robertson Milne: Neuronophagy, Review of Neurology and Psychiatry. Vol. VII, 1909, p. 587.

C. Oppenheim: Ueber protoplasmatische Glia Structuren. Archiv f. Psychiatrie und Nervenkrankheiten, Vol. XLIV, 1908, p. 1217.

S. Rosenthal: Experimentelle Studien ueber amœboide umwandlung der Neuroglia. Nissl's Arbeiten B. VI, H. I, 1913, p. 89.

A. Van Gehuchten: Anatomie du systeme Nerveux de l'Homme, 1906. 